\title{
Juridical Analysis of Interpretation of Medical Negligence on the Legal Protection of Doctor
}

\author{
Dian Andriani Ratna Dewi ${ }^{1}$, Megawati Barthos ${ }^{2}$ \\ Student at Doctoral of Law, Universitas Borobudur Jakarta \\ \{dianunborr@gmail.com ${ }^{1}$, megawati_barthos@borobudur.ac.id²
}

\begin{abstract}
Legal interpretations differences in medical negligence are still often encountered in the process of resolving cases of a medical action committed by a doctor on suspicion of medical negligence. This difference is the difference in determining the existence of negligent elements according to medicine and the Criminal Code. The application of the elements of negligence in ordinary criminal acts (KUHP) which is the focus is the result (gevolg), while in medical assessment what is important is not the result, but the cause/causes. If there is no element of fault/negligence, then doctors cannot be blamed and prosecuted legally. Here the importance of legal protection for doctors is because a doctor has ethical obligations and professional obligations. The legal provisions for the protection of doctors are contained in Law Number 29 of 2004 concerning Medical Practice and Law Number 36 of 2009 concerning Health. Also, the role of MKDKI is very important in providing opinions and decisions in determining whether there is medical negligence. This study aims to determine the juridical interpretation of medical negligence on the legal protection of doctors. This research is normative legal research. The approach used in this research is a statutory approach and a conceptual approach.
\end{abstract}

Keywords: Medical Negligence; Legal Protection

\section{Introduction}

The development of the health sector is aimed at increasing awareness, willingness, and ability to live a healthy life for everyone to achieve an optimal degree of health as one of the elements of welfare as mandated by the Preamble to the 1945 Constitution of the Republic of Indonesia. Doctors and dentists as one of the main components in providing health services to the community have a very important role because they are directly related to the provision of health services and the quality of services provided. Therefore, to provide protection and legal certainty to health service providers, such as doctors and dentists, legal protection is required in the implementation of medical practice.

The importance of a doctor's legal protection is because a doctor has ethical obligations and professional obligations to provide medical services or help patients. These ethical obligations and professional obligations also require doctors to make maximum efforts in helping patients without choosing the patient's condition, whether the patient's condition can be cured or saved or the patient's condition has little hope of being saved. This creates a dilemma for doctors. This dilemma makes doctors a profession that is prone to blame, even 
prone to being sued or prosecuted by the public or patients [1]. This happens because the public or patients, if there is a loss that results in physical disability or death, always consider it a form of medical negligence of a doctor who must be held legally responsible.

In Indonesia, in general, the provisions for the protection of doctor's law are contained in Law Number 29 of 2004 concerning Medical Practice or hereinafter referred to as Law No. 29 of 2004, which states that doctors or dentists in practicing medicine have the right to obtain legal protection as long as they carry out their duties following professional standards and standard operating procedures [2]. Then Law Number 36 the Year 2009 concerning Health or hereinafter referred to as Law No. 36 of 2009, states that health workers are entitled to compensation and legal protection in carrying out their duties according to their profession [3]. Furthermore, Law Number 36 of 2014 concerning Health Workers, or hereinafter referred to as Law No. 36 of 2014, states that in carrying out their practice Health Workers have the right to legal protection under the provisions of laws and regulations [4]. The importance of legal protection is due to the increasing number of lawsuits filed by the community today against doctors/dentists which are often identified with the failure of the healing efforts by doctors and dentists. Conversely, if the medical action is successful, it is considered excessive, even though doctors and dentists with their scientific and technological tools are only trying to cure them, and the failure to apply medical science and dentistry is not always synonymous with failure in action. Many factors cause the failure of healing efforts.

Besides the statutory regulations, the Indonesian Medical Discipline Honorary Council or MKDKI was formed to provide legal certainty and legal protection in the administration of medical practice. Also, a Medical Ethics Code Council (MKEK) was also formed. MKDKI is an assembly founded on the mandate of Law no. 29 of 2004, and MKEK was created by the Indonesian Doctors Association (IDI). Both are responsible for two different organizations. MKEK is responsible to IDI and MKDKI is responsible to the Minister of Health. The two of them are closely related to each other and provide mutual support.

MKDKI is an institution that has the authority to determine whether or not there are mistakes committed by doctors and dentists in the application of medical and dental disciplines and to determine sanctions [5] and has the authority to examine and give decisions on complaints related to the discipline of doctors and dentists [6]. The procedure is regulated by the Indonesian Medical Council Regulation Number 2 of 2011 concerning Procedures for Handling Cases of Alleged Violation of Doctor's Discipline.

As has been stated, the rampant lawsuits are due to different interpretations of "medical negligence" which result in patients experiencing losses in the form of physical disabilities or death according to the perspective of the medical community and law enforcement officials. According to a medical perspective, the occurrence of what is called medical negligence is not an intentional form of causing harm to someone. However, according to the perspective of criminal law, in particular, it is considered an intentional loss for others.

These differences in interpretation make it very interesting to research more focused and deeply from the perspective of constitutional law science in the form of a juridical analysis of medical negligence interpretation of the legal protection of doctors. Assessing how medical negligence can be interpreted from the perspective of Law no. 29 of 2004, and Law no. 36 of 2009 with the Criminal Code.

\section{Research Problem}

Based on the above background, the formulation of the research problem is as follows: 
How is the juridical analysis of medical negligence interpretation of the legal protection of doctors?

\section{Literature Review}

\subsection{Abnormality Concept (Culpa)}

According to Sutan Remy Sjahdeini, the word negligence or negligence in English is also referred to as "negligence" or "carelessness", or "carelessness". The term "negligence" in Dutch is "schuld". His opponent's schuld (negligence) is "opzet" (deliberate). In Latin, "negligence" is "culpa" and "willfulness" is "dolus" [7].

Furthermore, Sutan Remy Sjahdeini said that "negligence" (culpa) is "the mindless attitude of the perpetrator of an act and does not take into account the consequences that will arise from his actions which can be in the form of material loss, either in the form of property damage or financial loss, or causing physical or psychological injury, or even death, to others". Meanwhile, "deliberate" (dolus) is "the mental attitude of the doer of an act who knowingly and consciously knows the consequences that will arise on others from his actions and deliberately wants the consequences arising from his actions to occur" [8].

Basically, negligence occurs when someone does something that should not be done or does not do something that should be done by other people who have the same qualifications in the same circumstances and situations. The word negligence from the word negligent (culpa) in the broad sense means an error in general, while in the narrow sense it is a form of error in the form of neglect. The reason why a culpa is an element of error is when a situation, which is such a danger to the safety of people or property or incurs irreparable harm to someone [9].

\subsection{Negligence According to the Criminal Code}

In the Criminal Code (KUHP) Article 359, negligence is usually referred to as error, carelessness, or negligence. Article 359 of the Criminal Code reads: "Whoever because of his/her mistake (negligence) causes another person to die, is punishable by a maximum imprisonment of five years or maximum imprisonment of one year. R. Soesilo in the explanation of Article 359 of the Criminal Code said that "because of his fault" is the same as being careless, neglecting to forget, very inattentive [10]. In criminal law, negligence, error, carelessness, or negligence is called a culpa.

According to Wirjono, the meaning of culpa is "mistake in general", but in legal science, it has a technical meaning, namely a kind of error by the perpetrator of a criminal act that is not as severe as deliberate action, namely not being careful so that an accidental result occurs [11]. According to Langmeyer, the omission is a very gecompliceerd structure. He contains an incorrect part in outward action and points to a certain mental state and on the other the mental state itself [12]. Jan Remmelink said that in essence, culpa includes less (careful) thinking, lack of knowledge, or acting less purposefully. According to Jan Remmelink, the matter of culpa here clearly refers to a person's psychic abilities and therefore it can be said that culpa means not or lacking in realizing (beforehand the possibility of arising) the fatal consequences of that person's actions - even though it is easy to do and therefore should be done [13].

Regarding the measure of negligence in criminal law, Jan Remmelink said that according to the MVA (memory of answers) from the government, the benchmark for lawmakers was not diligentissimus pater familias (the highest precaution of the head of the family), but the citizens in general. The conditions for the imposition of the crime were sufficient carelessness, 
sufficient carelessness; not a culpa levis (minor negligence) but a culpa lata (major negligence) [14].

\subsection{Medical Negligence}

Negligence in medical law is often called negligence. Negligence is a human thing that is often experienced by humans because humans are not perfect. According to Guwandi, a person is said to be negligent when he acts indifferently or indifferently. Not paying attention to the interests of others is customary in the social order of society [15].

According to Sutan Remy Sjahdeini, concerning "Medical Actions" from Medical Personnel (doctors) to patients, what is meant by "negligence" is "actions taken by a Medical Personnel without being careful as should be done by a person. Medical personnel in carrying out their obligations so that patients for whom they are responsible avoid injury or death as a direct result of the actions taken by the Medical Personnel concerned" [16].

The occurrence of medical negligence can be caused by the doctor's lack of knowledge of the patient's disease or the doctor's lack of knowledge of medical science. Medical negligence can occur because doctors do not follow standard operating procedures, professional standards, and according to the medical profession, it is deemed to violate the medical code of ethics, resulting in losses in the form of physical disabilities and death.

In Indonesia, some scholars or experts distinguish negligence into two forms, namely medical and ethical negligence, juridical medical negligence (civil law, criminal law, and administrative law) [17]. Medical ethical negligence is a doctor committing an act that is contrary to medical ethics. Medical ethics is as stated in the Indonesian Medical Ethics Code (Kodeki) which contains or is a set of ethical standards, principles, rules, or norms that apply to doctors [18].

\subsection{Legal Protection}

The term legal protection in English is known as legal protection, while in Dutch it is known as rechts bescherming. Etymologically, legal protection consists of two syllables, namely protection and law. In the Big Indonesian Dictionary, protection means (1) a place of refuge, (2) things (actions and so on), (3) processes, methods, actions to protect [19]. The definition of law is a set of principles and rules governing human relations in society, whether it is kinship, village or village, or a country [20]. One of the most important functions of law is to achieve order in human life in society [21].

Legal protection is all efforts to fulfill rights and assisting to provide a sense of security to witnesses and/or victims, which can be realized in forms, such as through restitution, compensation, medical services, and legal assistance [22]. Philipus M. Hadjon said that legal protection is the protection of dignity and recognition of human rights owned by legal subjects based on legal provisions from arbitrariness or as a collection of rules or rules that can protect one thing from other things [23].

The principles of legal protection in Indonesia are based on Pancasila as the ideology and the basis of the state which is based on the concept of a rule of law (Rechstaat). The principle of protection of Indonesian law emphasizes the principle of the legal protection of human dignity which is rooted in Pancasila. The principle of legal protection against government actions rests on and originates from the concept of recognition and protection of human rights which is a concept that was born from western history, which is directed to the limitation and placement of obligations by society and the government [24]. 


\section{Research Method}

This research is legal research. This type of research is normative law research. The approach of this research is a statute approach and a conceptual approach [25] related to the interpretation of medical negligence on the legal protection of doctors.

\section{Results and Discussion}

Until now, there are still differences of opinion regarding the interpretation of medical negligence between law enforcers and medical circles in determining the assessment of the elements of medical negligence. This difference in perception is of course very detrimental to medical circles who experience legal problems with complaints of patients who feel aggrieved as a result of a medical action carried out by a doctor with the alleged occurrence of negligence. This is due to the confusion of understanding and views that confuse professional ethics with legal norms. Often both the general public and law enforcers equate the term medical malpractice (medical malpractice) with medical negligence so that an incorrect medical action can be called malpractice as well as a violation of professional ethics.

In medical jurisprudence, there is a formulation of negligence that has been universally accepted, namely "Negligence is a reasonable thoroughness, not doing what another person with due care and care would do naturally, or doing what someone else with reasonable accuracy. Just don't do it'". This formula has the meaning that negligence includes two things, such as because of doing something that should not be done or because it does not do something that should be done, in other words, negligence occurs when a person commits the act because he/she neglects the obligations according to the order of life the society that applies should not be done by him [26]. Negligence is not a violation of law or a crime if it does not bring harm or a flag to another person and that person can accept it. If the negligence causes material loss, injures, and even takes the life of another person, then the negligence is serious (culpa lata) and can be classified as a criminal act. Negligence occurs when someone accidentally, does something that should not be done or does not do something that should be done by people who have the same qualifications in a situation and the same situation [27]. Often what happens is that the general public/patients feel aggrieved or the doctor's medical service or action, especially if the loss results in death, physical disability always blames the doctor, which results in complaints or filing civil or criminal lawsuits to law enforcement agencies which incidentally differ in understanding/interpretation of medical negligence.

In fact, what happened was not due to medical errors. However, it is caused by other medical causes that can cause harm to the patient, such as experiencing physical disability or death, so that the patient complains about the problem to law enforcement agencies and is often linked to Article 359 of the Criminal Code. Even if medical negligence occurs, it doesn't have to end in the realm of law. It should be noted that this negligence can be in the form of deviations from medical profession standards and/or standard operating procedures.

As is known according to health legislation in Indonesia, it does not use the term negligence. This is because both Law no. 29 of 2004 and Law no. 36 of 2009 do not explicitly provide a definite definition of negligence. This can be seen in Law no. 29 of 2004, there is no omission formula/word. Considering that this law is a product devoted to the medical profession, according to the doctors, the word negligence is quite connotative, and that the term is part of an error in criminal law. The basis for the consideration of the formation of this 
law is to provide protection and legal certainty for health service recipients, doctors, and dentists [28].

UU no. 29 of 2004 uses the term violation of medical discipline. The term medical discipline is contained in the explanation of this law, which states something related to the provision of scientific application in the implementation of services that doctors and dentists must follow [29]. The medical discipline includes professional standards, service standards, and operational standards.

Concerning Article 359 of the Criminal Code, the standard of medical services can serve as a measure that determines the medical negligence of a doctor who is suspected of committing an error. One of the elements of the offense that must be proven in the formulation of Article 359 of the Criminal Code is negligence. The element of negligence has at least two conditions: in committing an act the defendant was not careful and the consequences arising from negligence must be imagined first [30].

However, Article 359 of the Criminal Code cannot simply be applied to medical negligence. Moreover, the Panel of Judges made consideration in the court case to sentence a doctor who is considered guilty of negligence. At least to measure this negligence, it is very important to consider the opinions and decisions of medical professional organizations, namely the Indonesian Medical Discipline Honorary Council (MKDKI) and the Medical Ethics Honorary Council (MKEK) as a form of legal protection for doctors. Often what happens is that the Panel of Judges ignores the opinions and decisions of MKDKI and MKEK as material for consideration, but tends to judge the element of negligence only based on the opinion of expert witnesses or prosecutors, as well as the patient's attorney at trial. Here the importance of MKDKI and MKEK opinions and decisions regarding the interpretation of medical negligence as a form of legal protection for doctors.

The problem of lawsuits is due to different interpretations of medical negligence by law enforcement officials. Often law enforcement officials accept complaints from patients or their families who feel aggrieved by the suspicion of medical negligence by doctors on the grounds of serving the public. The difference in interpretation is quite significant, namely the difference in the application of the elements of negligence, namely in the ordinary crime (KUHP) the focus is the result (gevolg), while in medical assessments what is important is not the result, but the cause/cause. Thus, the Panel of Judges sometimes only adheres to the applied article by ignoring the opinions and decisions of MKDKI.

The essence of the difference between ordinary crime and medical crime lies in the study of the crime. The study of ordinary crime lies in the consequences of a crime, while in medical crimes it studies the cause of the crime. In a medical crime, related to negligence (culpa), the responsibility must be proven concerning a professional error, for example, a misdiagnosis or an incorrect treatment method. Errors in medical action generally occur due to negligence committed by doctors, where the standard of error in carrying out medical profession duties in the form of negligence in criminal law is gross negligence (culpa lata), not minor negligence (culpa levis).

Determination of medical negligence must normatively be based on the treatment efforts (inspanningverbintenis) given by the doctor/dentist to the patient. Thus, the determination of the level of error regarding the presence or absence of a doctor/dentist's negligence must be distinguished, namely: The working period of doctors with average abilities, general practitioners with experts, health facilities available at the time of the medical action and supporting factors. Other influential in the medical actions that have been performed by doctors. 
Please note, negligence (culpa) does not include an act against the law if it does not cause harm to others, this is contained in the legal doctrine of "de minimus non curat lex" (the law does not interfere with trivial matters), but the exception is for serious negligence (culpa lata) which causes harm not only material but also the life of a patient. In connection with gross negligence (culpa lata) as stipulated in Article 359 of the Criminal Code, which reads "Anyone who due to his / her negligence causes the death of another person is punished with a maximum imprisonment of five years or a maximum imprisonment of one year". Serious negligence (culpa lata) is due to the negligence and lack of professional attitude of a doctor, causing the patient to die [31].

Generally, medical negligence according to Law no. 29 of 2004 is divided into three. First, violations against Kodeki are recognized as ethical violations. Second, violations against medical disciplines include violations of professional standards and standard operating procedures. Third, violations of law, where the consequences of the doctor's actions cause physical or material harm.

According to the World Medical Association (WMA), the term medical negligence is "medical malpractice involves the physician's failure to conform to the standard of care for treatment of the patient's condition, or lack of skill, or negligence in providing care to the patient, which is the direct cause of an injury to the patient". The WMA states that not all medical failures are the result of medical malpractice, due to an unforeseeable adverse event that occurs when standardized medical treatment is performed but results in injury to the patient [32].

An act or medical action is called negligence if it fulfills the four elements below [33]:

a. The duty or obligation of medical personnel to take any medical action or not to take certain actions against certain patients in certain situations and conditions. The basis for this obligation is the existence of a professional-contractual relationship between medical personnel and their patients, which creates general obligations as a result of this relationship and professional obligations for the medical personnel. Professional obligations are described in the professional oath, professional ethics, various service standards, and various operational procedures. From a legal perspective, these obligations are signs that must be followed to achieve protection, both for service providers and for service recipients; or thus to achieve optimum safety.

b. Dereliction of duty or deviation of obligations. In assessing obligations in the form of a certain service standard, we must first determine the qualifications of the service provider (person and institution), in what situations, and under what conditions. A service standard is generally made based on minimum requirements which must be given or provided (das sein), but sometimes a standard also describes what should be done or provided (das sollen). The two descriptions of the standard must be interpreted carefully. Likewise, a standard generally talks about a situation and state that is "normal", so it must be corrected first to apply to certain situations and conditions. In this case, one must pay attention to the existence of the Golden Rule which states "What is right (or wrong) for one person in a given situation is similarly right (or wrong) for any other in an identical situation".

c. Damage or loss. What is meant by loss is everything that is felt by a patient as a result of a health / medical service provided by the service provider. So, this element of loss is closely related to the element of the causal relationship. Losses can be in the form of material losses and immaterial losses. Losses that are material in nature can be in the form of real losses and losses as a result of lost opportunities. The real loss is the "real cost" or costs incurred for the treatment/treatment of the resulting illness or injury, whether it has been incurred until the time the lawsuit was filed or the costs that will still be incurred for 
treatment/recovery. Losses can also be in the form of losses due to lost opportunities to earn income. Another loss that is more difficult to calculate is the immaterial loss as a result of illness or disability or death of a person.

d. Direct causal relationship or a real cause and effect relationship. In this case, there must be a cause-and-effect relationship between deviation from obligations and losses, which are at least a "proximate cause".

A lawsuit due to medical negligence must prove the existence of the four elements above, and if one of them cannot be proven, then the lawsuit can be deemed insufficient evidence. Thus, the allegation of medical negligence by a doctor cannot be used as a reason to file a criminal or civil lawsuit.

\section{Conclusion and Suggestion}

\subsection{Conclusion}

The different interpretations of medical negligence have become a dilemma for doctors to become a profession that is prone to be blamed, even prone to being sued or prosecuted by the public or patients. Evidence of medical negligence must meet the requirements for elements of negligence. Here, the role of MKDKI is very important in providing opinions and decisions in determining whether there is an element of medical negligence so that a transparent, accountable and just legal protection for doctors can be realized.

\subsection{Suggestion}

The state should provide legal protection to doctors in carrying out their duties and professions as long as they do not violate statutory regulations in addition to protecting the public or patients as recipients of health services. There is a need for legal provisions regarding specific legal procedures in assessing and determining whether or not a doctor is negligent in carrying out his profession, by imposing a tiered examination process, starting with the ethical and disciplinary examination processes in MKEK and MKDKI as a first-level examination process which also functions as an assessor whether there is a violation of the law or not. If the results of the examination at MKEK and MKDKI show indications of legal violations due to medical negligence, they will be forwarded or submitted to law enforcers.

\section{References}

[1] IDI Minta Dokter Diberi Perlindungan Hukum. page $=$ web.Berita\&id=10159 (4 September 2014).

[2] Undang-Undang Republik Indonesia Nomor 29 Tahun 2004 tentang Praktik Kedokteran.

[3] Undang-Undang Republik Indonesia Nomor 36 Tahun 2009 tentang Kesehatan.

[4] Undang-Undang Republik Indonesia Nomor 36 Tahun 2014 tentang Tenaga Kesehatan.

[5] Undang-Undang Republik Indonesia Nomor 29 Tahun 2004 tentang Praktik Kedokteran.

[6] Undang-Undang Republik Indonesia Nomor 29 Tahun 2004 tentang Praktik Kedokteran. 
[7] Sjahdeini, Sutan Remy.: Hukum Kesehatan Tentang Malpraktik Medis. Jilid I. Tanpa Penerbit, Jakarta, Tanpa Tahun.

[8] Sjahdeini, Sutan Remy.: Hukum Kesehatan Tentang Malpraktik Medis. Jilid I. Tanpa Penerbit, Jakarta, Tanpa Tahun.

[9] Paidun, Hendri, Tinjauan Terhadap Tindak Pidana Kealpaan Yang Menyebabkan Matinya Orang Yang Dilakukan Oleh Pengemudi Kendaraan Bermotor, Jurnal Lex Crimen, Vol. II, No. 7, November 2013.

[10] Soesilo, R.: Kitab Undang-Undang Hukum Pidana (KUHP) Serta KomentarKomentarnya Lengkap Pasal Demi Pasal.

[11] Prodjodikoro, Wirjono.: Asas-Asas Hukum Pidana di Indonesia. Refika Aditama, Jakarta (2003)

[12] Moeljatno.: Perbuatan Pidana dan Pertanggung Jawabannya Dalam Hukum Pidana. Rinneka Cipta, Jakarta (1993)

[13] Remmelink, Jan.: Hukum Pidana. Gramedia Pustaka Utama, Jakarta (2003)

[15] Guwandi.: Pengantar Ilmu Hukum Medik \& Bio-etika. Balai Penerbit Fakultas Kedokteran Universitas Indonesia, Jakarta (2009)

[16] Sjahdeini, Sutan Remy.: Hukum Kesehatan Tentang Malpraktik Medis. Jilid I. Tanpa Penerbit, Jakarta, Tanpa Tahun.

[17] Soedjatmiko, H.M.: Masalah Medik dalam Malpraktik Yuridik. Kumpulan Makalah Seminar tentang Etika dan Hukum Kedokteran (2001).

[18] Soedjatmiko, H.M.: Masalah Medik dalam Malpraktik Yuridik. Kumpulan Makalah Seminar tentang Etika dan Hukum Kedokteran (2001).

[19] Kamus Besar Bahasa Indoesia (KBBI) Online.__ https://kbbi.web.id/ perlindungan

[20] Kusumaatmadja, Mochtar.: Pengantar Ilmu Hukum. Alumni, Bandung (2009).

[21] Kusumaatmadja, Mochtar.: Pengantar Ilmu Hukum. Alumni, Bandung (2009).

[22] Soekanto, Soerjono.: Pengantar Penelitian Hukum. UI Press., Jakarta (1984).

[23] Hadjon, Philipus M.: Perlindungan Hukum Bagi Rakyat Indonesia. Bina Ilmu, Surabaya (1987).

[24] Hadjon, Philipus M.: Perlindungan Hukum Bagi Rakyat Indonesia. Bina Ilmu, Surabaya (1987).

[25] Marzuki, Peter Mahmud.: Penelitian Hukum. Kencana, Jakarta (2008).

[26] Guwandi.: Misdiagnosis atau Malpraktek. Jurnal Perhimpunan Rumah Sakit Seluruh Indonesia. Volume 3 (2003)

[27] Hanafiah, Jusuf dan Amri Amir.: Etika Kedokteran dan Hukum Kesehatan. Buku Kedokteran EGC (1999).

[28] Undang-Undang Republik Indonesia Nomor 29 Tahun 2004 tentang Praktik Kedokteran.

[29] Undang-Undang Republik Indonesia Nomor 29 Tahun 2004 tentang Praktik Kedokteran.

[30] Suharto.: Hukum Pidana Materiil: Unsur-Unsur Obyektif Sebagai Dasar Dakwaan. Sinar Grafika, Jakarta (2002).

[31] Kelalaian Dalam (Culpa) Malpraktek Kedokteran. kedokteran/ https://lbhyogyakarta.org/2013/08/22/kelalaian-culpa-dalam-malpraktek-

[32] Healy, John.: Medical Negligence: Common Law Perspectives. Sweet and Maxwell, London (1999). 
[33] Sampurno, Budi.: Laporan Akhir Tim Kompendium Hukum Kesehatan, Pusat Penelitian dan Pengembangan Sistem Hukum Nasional. Badan Pembinaan Hukum Nasional Kementerian Hukum dan HAM RI Tahun 2011, Jakarta (2011). 